\title{
ANALISIS RAWAN KEKERINGAN LAHAN PADI KABUPATEN BANYUWANGI JAWA TIMUR
}

\author{
Nuryadi $^{1 *}$, Suci Agustiarini ${ }^{2}$ \\ ${ }^{1}$ Sekolah Tinggi Meteorologi Klimatologi dan Geofisika, Tangerang Selatan \\ ${ }^{2}$ Badan Meteorologi Klimatologi dan Geofisika, Jakarta \\ Email: bintaro2001us@yahoo.com
}

\begin{abstract}
ABSTRAK
Secara umum pengertian kekeringan adalah ketersediaan air yang kurang dari kebutuhan air untuk kebutuhan hidup, pertanian, kegiatan ekonomi, dan lingkungan. Terkait dengan produksi pangan maka kekeringan pertanian sangat berpengaruh terhadap kegiatan budi daya pangan di suatu wilayah. Ketersediaan air tanah sangat penting untuk menentukan tingkat rawan kekeringan lahan padi di Kabupaten Banyuwangi. Data yang digunakan adalah curah hujan bulanan periode 1981-2010 dari 32 pos hujan dan stasiun BKMG di Kabupaten Banyuwangi. Analisis tingkat kekeringan menggunakan pembobotan air tanah tersedia dan tipe iklim Oldeman pada setiap pos hujan. Kabupaten Banyuwangi berdasarkan klasifikasi iklim Oldeman terbagi menjadi 9 tipe iklim mulai dari iklim yang basah (B1) hingga kering (D dan E). Pada Februari, Maret, dan April ketersediaan air tanah lebih banyak dibandingkan bulan lainnya, sedangkan Agustus, September dan Oktober memiliki ketersediaan air tanah terendah. Wilayah bagian barat Banyuwangi memiliki air tersedia yang lebih besar dibandingkan bagian timur. Tingkat kekeringan lahan padi bervariasi secara temporal dan spasial mulai dari sangat rawan hingga aman. Tingkat kering dan rawan kekeringan padi puncaknya terjadi pada September dan Oktober dengan cakupan wilayah yang paling luas. Sebagian besar wilayah mengalami tingkat yang aman untuk lahan padi adalah pada Januari, Febuari, Maret dan April.
\end{abstract}

Kata kunci: Oldeman, air tanah tersedia, tingkat kekeringan.

\begin{abstract}
In general, the definition of drought is the availability of water that is less than the need for water for the necessities of life, agriculture, economic activity, and environment. Associated with food production, agricultural drought is very influential on cultivation activities on food production in a region. Groundwater availability is essential to determine the level of drought-prone rice fields in Banyuwangi District. The data used are monthly rainfall period 1981-2010 from 32 rain post and BKMG station in Banyuwangi Regency. Drought level analysis using available groundwater weighting and Oldeman climate type on each rain post. Banyuwangi Regency based on Oldeman climate classification is divided into 9 climate types ranging from wet climate (B1) to dry (D and E). In February, March, and April the availability of ground water is higher than in other months, whereas August, September and October have the lowest groundwater availability. The western part of Banyuwangi has more water available than the eastern part. The degree of dryness of paddy land varies temporally and spatially from very vulnerable to safe. The dry and prone levels of peak rice dryness occur in September and October with the widest coverage of the area. Most of the areas experiencing safe levels for paddy fields are in January, February, March and April.
\end{abstract}

Keywords: Oldeman, groundwater available, drought rate.

\section{PENDAHUluaN}

Kekeringan merupakan salah satu bencana yang sulit dicegah dan kejadiannya dapat berulang. Secara umum pengertian kekeringan adalah ketersediaan air yang kurang dari kebutuhan air untuk kebutuhan hidup, pertanian, kegiatan ekonomi, dan lingkungan (Sonjaya, 2007). Berbagai macam jenis kekeringan, tapi terkait produksi pangan, kekeringan pertanian sangat berpengaruh bagi kegiatan budi daya tanaman pertanian. Terjadinya kekeringan di suatu daerah pertanian dapat menjadi kendala dalam 
peningkatan produksi pangan di daerah tersebut.

Intensitas curah hujan sangat diperlukan dalam pembuatan informasi mengenai ketersediaan air tanah, terutama pada tanaman pertanian di lahan tadah hujan dimana sumber air hanya berasal dari curah hujan. Curah hujan juga berperan penting dalam pembuatan klasifikasi iklim Oldeman yang mudah dan praktis menggunakan konsep bulan basah dan bulan kering dengan memperhatikan peluang hujan, hujan efektif dan kebutuhan air untuk tanaman. Informasi ketersediaan air tanah serta klasifikasi Oldeman ini penting dalam pembuatan rencana penanaman serta mengatur langkah strategis selanjutnya untuk menghadapi kekeringan.

Kabupaten Banyuwangi merupakan salah satu wilayah dengan potensi pertanian yang besar. Hal ini terbukti dengan sumbangsih besar sektor pertanian terhadap produksi padi di Jawa Timur sehingga dikatakan Banyuwangi sebagai lumbung padi di Provinsi Jawa Timur. Kabupaten Banyuwangi merupakan kabupaten terluas di Jawa Timur yang terletak di 7.43 LS - 8.46 LS dan 113.53 BT - 114.38 BT dengan luas wilayah mencapai $5782,5 \mathrm{~km}^{2}$. Topografi wilayah Kabupaten Banyuwangi cukup beragam mulai dari dataran rendah hingga pegunungan (Sandy, 1987). Kegiatan masyarakat yang dominan memilih sektor pertanian sebagai mata pencaharian, maka pertanian menjadi pilar penting perekonomian Banyuwangi khususnya padi dan jagung.

Menurut catatan Dinas Pertanian Perkebunan Peternakan dan Kehutanan Kabupaten Banyuwangi tahun 2014 dalam beberapa tahun terakhir produksi padi di Banyuwangi mengalami peningkatan produksi. Namun, pada tahun 2011 mengalami penurunan produksi sebesar $8.71 \%$ dibandingkan dengan saat ini. Terkait dengan hal ini, untuk mencegah penurunan tersebut serta meningkatkan produksi padi, perlu dilakukan strategi adaptasi dan mitigasi yang bersifat preventif. Salah satu langkah yang dapat dilakukan adalah penyediaan informasi iklim berupa analisis rawan kekeringan lahan padi di Kabupaten Banyuwangi.

\section{METODOLOGI}

\subsection{DATA}

Data yang digunakan adalah rata-rata curah hujan bulanan periode $1981 \mathrm{~s} / \mathrm{d} 2010$ dari 31 pos hujan kerjasama dan satu Stasiun Meteorologi di Kabupaten Banyuwangi. Data suhu udara bulanan periode $1995 \mathrm{~s} / \mathrm{d} 2002$ dari Stasiun Meteorologi Banyuwangi, serta data kapasitas lapang (KL) dan titik layu permanen (TLP) Kabupaten Banyuwangi (Pawitan, dkk., 1996).

\subsection{METODE}

\subsubsection{Klasifikasi Iklim Oldeman}

Klasifikasi iklim Oldeman sangat berguna khususnya dalam klasifikasi lahan pertanian tanaman pangan di Indonesia dengan menggunakan unsur curah hujan. Kriteria yang digunakan yaitu berdasarkan perhitungan bulan basah (BB) dan bulan kering (BK) berturutturut yang batasannya memperhatikan peluang hujan, hujan efektif dan kebutuhan air bagi tanaman (P3-TISDA, 2005).

Berdasarkan konsep yang dikemukakan Oldeman, maka dapat dihitung hujan bulanan yang diperlukan untuk padi sawah maupun palawija (misal X) dengan menggunakan series data hujan yang panjang, yaitu :

Padi sawah $\quad: 145=1,00(0,82 X-30)$

$$
\mathrm{X}=213 \mathrm{~mm} \text { per bulan }
$$

Palawija $\quad: 50=0,75(0,82 X-30)$

$$
\mathrm{X}=118 \mathrm{~mm} \text { per bulan }
$$

Nilai $213 \mathrm{~mm}$ dan $118 \mathrm{~mm}$, selanjutnya dibulatkan menjadi $200 \mathrm{~mm}$ dan $100 \mathrm{~mm}$, yang digunakan sebagai batas penentuan "Bulan Basah (BB)" dan "Bulan Kering (BK)"Jadi:

Bulan Basah (BB) : Bulan dengan ratarata curah hujan $>200 \mathrm{~mm}$

Bulan Kering (BK) : Bulan dengan ratarata curah hujan $<100 \mathrm{~mm}$

Dalam penentukan klasifikasi iklimnya, Oldeman menggunakan panjang periode bulan basah dan bulan kering "berturut-turut". Oldeman membagi menjadi 5 tipe utama berdasarkan dengan bulan basah (BB) dan 4 subdivisi yang didasarkan kepada bulan kering (BK).

Pembagian 5 tipe utama dan 4 subdivisi dijabarkan pada Tabel 1 sebagai berikut : 
Tabel 1. Kriteria Klasifikasi Iklim Oldeman

\begin{tabular}{|c|c|c|c|}
\hline $\begin{array}{c}\text { Tipe } \\
\text { Utama }\end{array}$ & $\begin{array}{c}\text { BB } \\
\text { Berturut- } \\
\text { turut }\end{array}$ & $\begin{array}{c}\text { Sub } \\
\text { Divisi }\end{array}$ & $\begin{array}{c}\text { BK } \\
\text { Berturut- } \\
\text { turut }\end{array}$ \\
\hline A & $>9$ & 1 & $<2$ \\
\hline B & $7-9$ & 2 & $2-3$ \\
\hline C & $5-6$ & 3 & $4-6$ \\
\hline D & $3-4$ & 4 & $>6$ \\
\hline E & $<3$ & & \\
\hline
\end{tabular}

Sumber : Oldeman (1982)

\subsubsection{Komponen Neraca Air Lahan}

\section{1) Presipitasi}

Presipitasi atau curahan, adalah cara pengembalian air dalam segala bentuk dari langit ke permukaan bumi. Pada daerah tropis, termasuk Indonesia, presipitasi umumnya berbentuk curah hujan.

Menurut Chang (1968), dalam perhitungan neraca air lahan, curah hujan merupakan variabel yang selalu berubah. Apabila perhitungan dilakukan untuk keperluan jangka panjang, maka tahap awal yang penting adalah menghitung peluang terjadinya curah hujan.

\section{2) Evapotranspirasi}

Kehilangan air dari tanah terjadi melalui dua proses yang berbeda, yaitu melalui evaporasi dari permukaan tanah dan transpirasi dari permukaan daun. Dalam prakteknya, penentuan kehilangan air secara terpisah melalui kedua proses tersebut sulit dilakukan atau ditentukan, sehingga pengukuran jumlah air yang hilang dihitung sebagai total air yang hilang melalui evaporasi dan transpirasi, yang disebut dengan evapotranspirasi (Nasir, 1991).

Nilai ETP standar (vegetasi rumput) dengan urutan prioritas sbb: ETP lisimeter, evaporasi kelas A dikali tetapan, ETP hasil perhitungan/estimasi menurut rumus Penman, Thorntwaite, Blaney Criddle dan seterusnya.

Berikut adalah rumus ETP dengan menggunakan metode Thorntwaite :

$\operatorname{ETp}=1.6\{10 t / I\}^{\text {a }}$

$\mathrm{i}=(\mathrm{t} / 5) 1.514 \quad \mathrm{I}=\Sigma \mathrm{i}$

$\mathrm{a}=675 \times 10^{\wedge}-9 \mathrm{I} 3-771 \times 10^{\wedge}-7 \mathrm{I} 2+1792$

x $10^{\wedge}-5 \mathrm{I}+0,49239$

$\mathrm{t}$ : suhu rata-rata bulanan

I : indeks panas

ETp : dalam satuan $\mathrm{cm}$ dan panjang hari 12 jam.
Rumus ETp koreksi untuk jumlah hari dan panjang hari :

ETp $_{\text {koreksi }}=(\mathrm{X} / 30) \times(\mathrm{Y} / 12) \times$ Etp

$\mathrm{X}=$ jumlah hari dalam sebulan tertentu.

$\mathrm{Y}=$ panjang hari pada bulan tertentu sesuai dengan lintang tempat.

Untuk neraca air tanaman, evapotranspirasi yang digunakan adalah evapotranspirasi tanaman (ETc) yang menunjukkan jumlah penguapan air yang terjadi pada tanaman sesuai dengan umur dan jenis tanaman selama masa pertumbuhan, yaitu :

ETc $=$ ETp $x$ kc

dimana kc adalah koefisien tanaman yang besarnya tergantung jenis tanaman, dan untuk padi nilai $\mathrm{kc}=1.13$ (Doorenbos dan Pruitt, 1976)

\section{3) Kandungan Air Tanah (KAT)}

Kandungan (kadar) air dalam tanah merupakan suatu sistem penyangga bagi tanaman untuk mengatur keseimbangan air dalam tanaman itu sendiri. Sumber air yang tersedia bagi tanaman adalah yang berada atau ditahan oleh zona perakaran. Air yang tersedia, adalah berupa air yang tertahan di dalam tanah antara kapasitas lapang dan titik layu permanen (Chang, 1968).

Kapasitas Lapang (water holding capacity), mekanismenya terjadi apabila infiltrasi saat berlangsungnya hujan dimana air akan mengalir ke dalam tanah akibat gaya gravitasi melalui pori-pori tanah dan menempati lapisan paling bawah. Jika tanah menjadi jenuh akan air dan tidak lagi dipengaruhi oleh gaya gravitasi, maka tanah dikatakan dalam keadaan kapasitas lapang (KL). Dengan demikian, kapasitas lapang merupakan jumlah air yang tertahan dalam tanah sesudah kelebihan air gravitasi mengalami drainase dan laju gerak turun dari air tersebut menurun. Kapasitas lapang dari suatu jenis tanah tergantung pada tekstur dan struktur tanah (Buckman and Brady, 1969).

Titik Layu Permanen (permanent wilting point) atau koefisien layu (wilting coeficient) merupakan batas bawah ketersediaan air dalam tanah untuk tanaman, dimana tanaman tidak dapat lagi menyerap air untuk pertumbuhannya. Pada saat titik layu permanen (TLP), kandungan (kadar) air tanah beragam yaitu mulai 30-40\% untuk tanah pasir halus, dan 30\% untuk tanah dengan tekstur liat halus (Chang, 1968).

\subsubsection{Prosedur Analisis Neraca Air Lahan}


Prosedur analisis NAL Thornwaite and Mather (1957) adalah dengan menyusun kolom isian pada tabel, dengan perhitungan sebagai berikut

2) Kolom Evapotranspirasi Potensial (ETP).

Nilai ETP standar (vegetasi rumput) hasil perhitungan/estimasi rumus Thorntwaite.

3) Kolom CH-ETP

Selisih nilai curah hujan dan evapotranspirasi potensial.

4) Kolom Akumulasi Potensial untuk penguapan (APWL)

Hasil-hasil negatif pada langkah 3) diakumulasikan bulan demi bulan sebagai nilai Accumulation Potensial of Water Loss (APWL) dan diisikan pada kolom ini.

5) Kolom kandungan air tanah (KAT)

Pertama tentukan kapasitas lapang (KL). Pengisian kolom KAT dimulai bulan pertama terjadi APWL berdasarkan tabel soil moisture retention atau hitungan rumus sbb:

$\mathrm{KAT}=\mathrm{KL} \times \mathrm{k}|\mathrm{APWL}|$

$\mathrm{k}=\mathrm{p}_{0}+\mathrm{p}_{1} / \mathrm{KL} \quad \mathrm{p}_{0}=1.000412351$

$\mathrm{p}_{1}=-1.073807306$

Kolom KAT bulan pertama dimana CH-ETP bernilai positif diisi dengan :

$\left(\mathrm{KAT}=\mathrm{KAT}_{\text {terakhir }}+\mathrm{CH}-\mathrm{ETP}\right) . \quad$ Begitu seterusnya hingga nilai $\mathrm{KAT}=\mathrm{KL}$ tercapai. Sejak bulan tersebut selama hujan masih berlebihan nilai KAT tetap konstan yaitu sama dengan KL.

6) Kolom Perubahan KAT (dKAT)

Nilai KAT dari suatu bulan tersebut dikurangi KAT bulan sebelumnya.

7) Kolom Evapotranspirasi Aktual (ETA)

Jika $\mathrm{CH}>$ ETP maka ETA = ETP. Pada bulan-bulan terjadi APWL $(\mathrm{CH}<\mathrm{ETP})$ maka $\mathrm{ETA}=\mathrm{CH}+|\mathrm{dKAT}|$.

8) Kolom Defisit (D)

$\mathrm{D}=$ ETP - ETA.

9) Kolom Surplus (S)

Surplus terjadi saat tidak ada $\mathrm{D}$, maka $\mathrm{S}=$ CH - ETP - dKAT.

\subsubsection{Analisis Rawan Kekeringan}

Tingkat rawan kekeringan dihitung berdasarkan penjumlahan nilai bobot tipe iklim Oldeman dan Air Tanah Tersedia. Nilai pembobotan disajikan pada tabel 2 berikut.

Tabel 2. Pembobotan Tingkat Rawan Kekeringan
1) Kolom Curah Hujan

Data $\mathrm{CH}$ rata-rata bulanan atau $\mathrm{CH}$ dengan peluang tertentu.

Selanjutnya, skor bobot nilai rawan kekeringan dikelompokkan menjadi tiga kelas, seperti pada tabel 3.

Tabel 3. Kelas Rawan Kekeringan

\begin{tabular}{|c|c|}
\hline Kelas Rawan Kekeringan & score \\
\hline Sangat Rawan & $<8$ \\
\hline Rawan & $8-10$ \\
\hline Aman & $>10$ \\
\hline
\end{tabular}

\section{HASIL DAN PEMBAHASAN}

\subsection{Tipe Iklim Oldeman}

Kabupaten Banyuwangi terbagi menjadi 9 tipe iklim Oldeman, yaitu tipe iklim B1, B2, C1, C2, C3, D2, D3, D4, dan E. Keragaman tipe iklim di Banyuwangi dapat disebabkan oleh kondisi topografi yang cukup beragam ketinggiannya yaitu disebelah barat lebih tinggi dari timur.

Berdasarkan kondisi tersebut bagian barat Banyuwangi cendrung iklimnya lebih basah dibandingkan bagian timur. Peta tipe iklim Oldeman disajikan pada gambar 1. Tipe iklim D4 merupakan wilayah terluas di Kabupaten Banyuwangi mencapai $1409.88 \mathrm{~km}^{2}$ dan terkecil adalah tipe iklim B1 yaitu sebesar $116.94 \mathrm{~km}^{2}$. Luas wilayah pada setiap tipe iklim Oldeman di Banyuwangi dapat dilihat pada tabel 4.

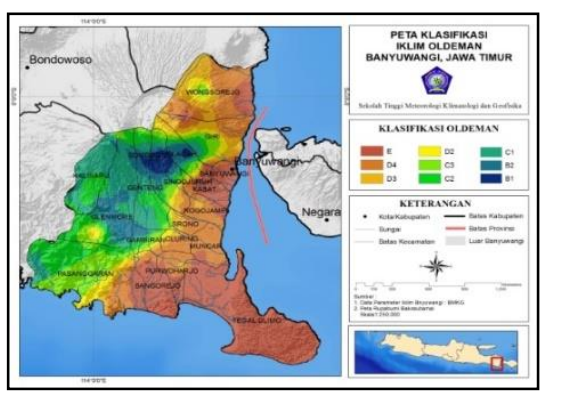

Gambar 1. Klasifikasi Tipe Iklim Oldeman

Tabel 4. Luas Wilayah pada Setiap Tipe Iklim Oldeman

\begin{tabular}{|c|c|c|c|}
\hline \multicolumn{2}{|c|}{ Tipe Iklim } & \multicolumn{2}{c|}{ Luas $\left(\mathbf{k m}^{\mathbf{2}}\right)$} \\
\hline \multicolumn{2}{|c|}{ B1 } & \multicolumn{2}{c|}{116,94} \\
\hline B2 & \multicolumn{2}{c|}{670,08} \\
\hline B 1 & \% ATS & Nilai Bobot \\
\hline Tipe Oldeman (Utama) & Nillai Bobot & \multirow{2}{*}{32} \\
\hline A & 5 & Sangat Kurang & 3 \\
\hline B & 4 & Kurang & 6 \\
\hline C & 3 & Sedang & 9 \\
\hline D & 2 & Cukup & 12 \\
\hline E & 1 & Sangat Cukup & 15 \\
\hline
\end{tabular}




\begin{tabular}{|c|c|}
\hline C2 & 718,48 \\
\hline C3 & 453,38 \\
\hline D2 & 523,33 \\
\hline D3 & 639,03 \\
\hline D4 & 1409,88 \\
\hline E & 707,68 \\
\hline
\end{tabular}

\subsection{Ketersediaan Air Tanah}

Berdasarkan data curah hujan, evapotranspirasi, dan kemampuan tanah menahan air, disusun perhitungan neraca air lahan padi untuk masingmasing pos hujan pada setiap tipe iklim Oldeman. Dari perhitungan neraca air lahan tersebut dapat diketahui persentase air tanah tersedia pada setiap bulan serta defisit dan surplus.

Nilai persentase tersebut selanjutnya diberi bobot untuk penentuan tingkat rawan kekeringannya. Grafik Ketersedian air tanah pada setiap pos hujan yang mewakili tipe iklim Oldeman B2, C2, D2 dan E di Kabupaten Banyuwangi seperti pada gambar 2, 3, 4 dan 5.

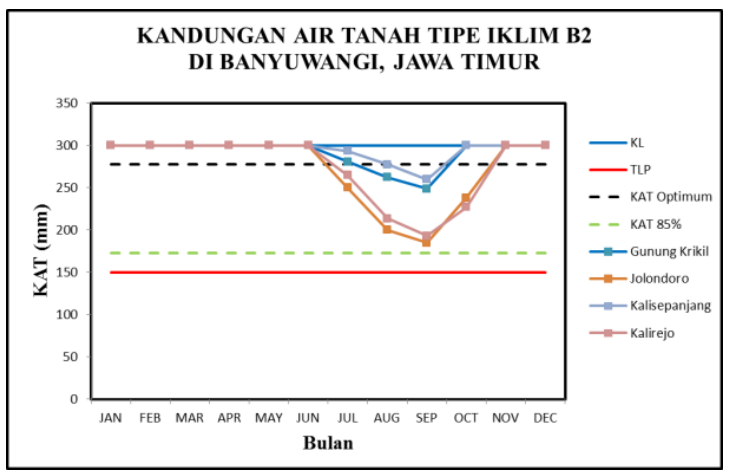

Gambar 3. Grafik KAT Pada Tipe Iklim C2

Ketersediaan air tanah untuk wilayah tipe iklim C2 kondisi surplus atau KAT melibihi KL terjadi selama 8-10 bulan sehingga sesuai untk melakukan 2 kali masa tanam selama setahun.

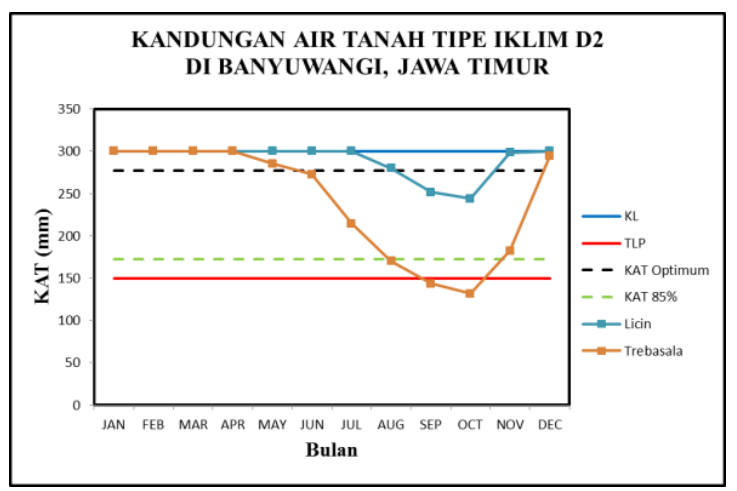

Gambar 4. Grafik KAT Pada Tipe Iklim D2
Ketersediaan air tanah untuk wilayah tipe iklim D2 menunjukkan kondisi surplus terjadi selama 6-9 bulan sehingga berpeluang memiliki masa tanam padi 1-2 kali dalam setahun.

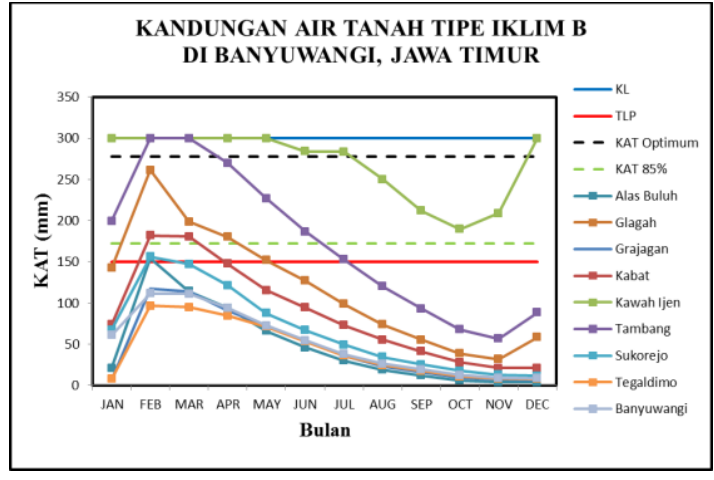

Gambar 5. Grafik KAT Pada Tipe Iklim E

\subsection{Peta Rawan Kekeringan}

\section{Bulan Januari dan Februari}

Pada bulan Januari, wilayah kekeringan menunjukkan sebagian besar bagian timur Banyuwangi rawan hingga sangat rawan terhadap kejadian kekeringan dan cenderung tidak bisa ditanami padi. Sedangkan wilayah yang aman untuk ditanami padi yaitu sekitar Kecamatan Pesanggrahan, Gambiran, Cluring, Singojuruh, Giri, Wongserejo, Glagah, Songgon, Genteng, Glenmore, dan Kalibaru.

Pada bulan Februari, sebagian besar wilayah aman untuk ditanami padi. Wilayah rawan kekeringan lebih sedikit dibanding bulan Januari yaitu meliputi bagian selatan sekitar Bangorejo, Purwoharjo, Tegaldelimo, serta Banyuwangi dan Kabat dan cenderung tidak bisa ditanami padi. 


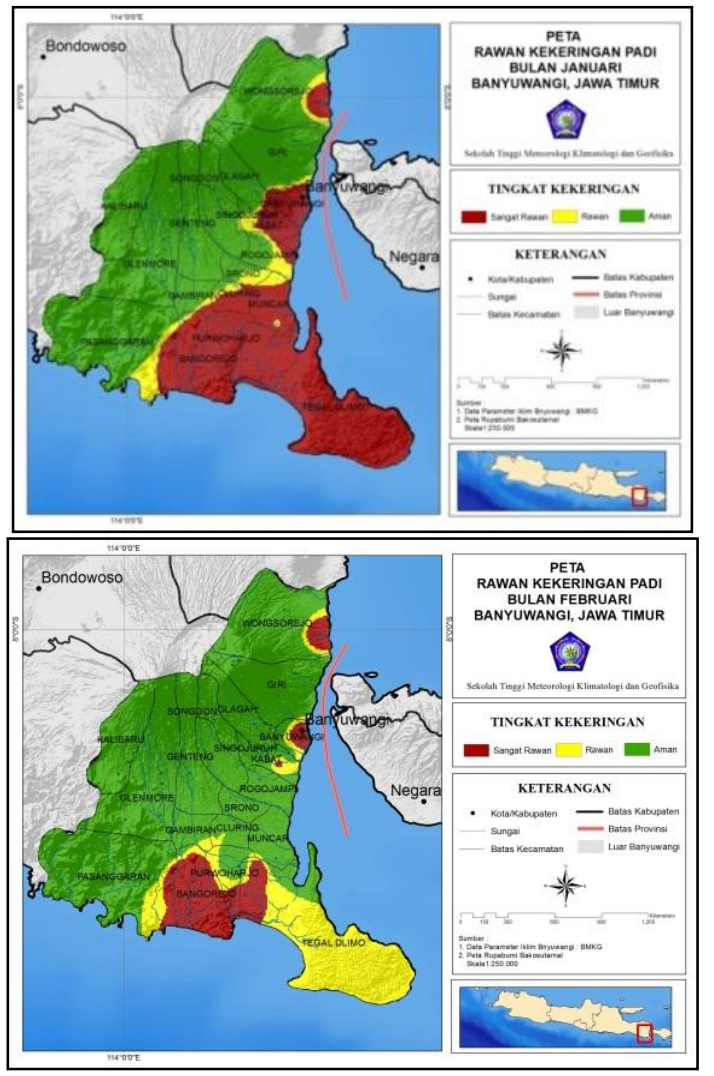

Gambar 6. Peta Kekeringan Lahan Padi Bulan Januari dan Febuari

\section{Bulan Maret dan April}

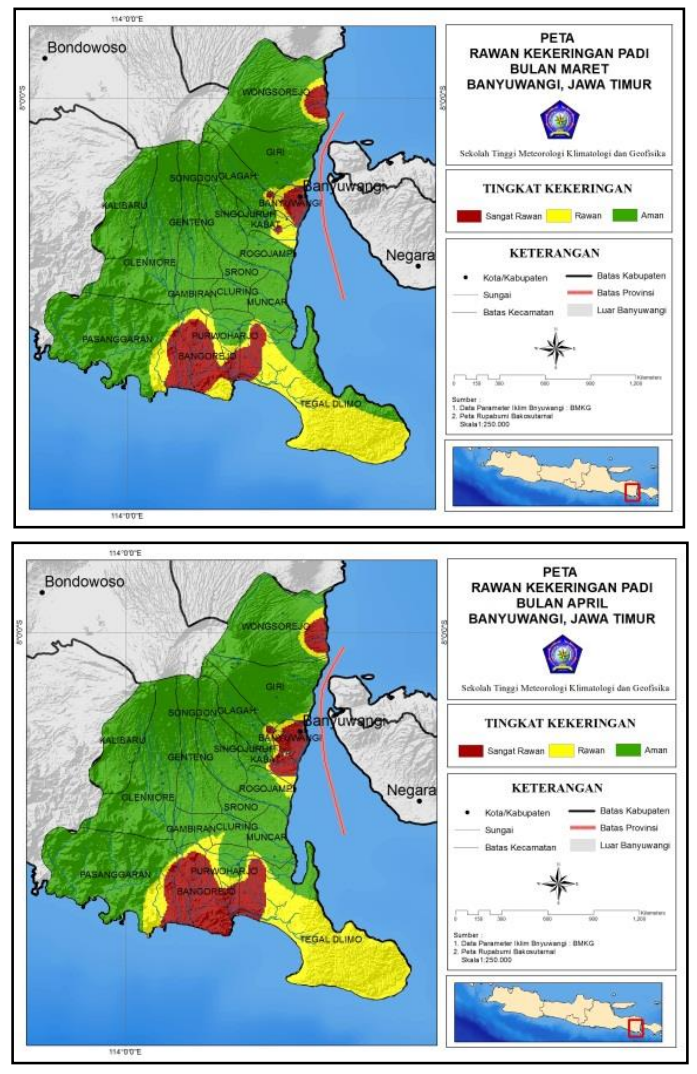

Gambar 7. Peta Kekeringan Lahan Padi Bulan Maret dan April
Pada bulan Maret, hampir sama dengan Febuari yaitu sebagian besar wilayah aman untuk ditanami padi. Wilayah rawan kekeringan lebih sedikit dibanding bulan Januari yaitu meliputi bagian selatan sekitar Bangorejo, Purwoharjo Tegaldelimo, serta Banyuwangi dan Kabat dan cenderung tidak bisa ditanami padi.

Pada bulan April, hampir sama dengan Maret yaitu sebagian besar wilayah aman untuk ditanami padi. Wilayah rawan kekeringan lebih sedikit dibanding bulan Januari yaitu meliputi bagian selatan sekitar Bangorejo, Purwoharjo, Tegaldelimo, serta Banyuwangi dan Kabat dan cenderung tidak bisa ditanami padi.

\section{Bulan Mei dan Juni}
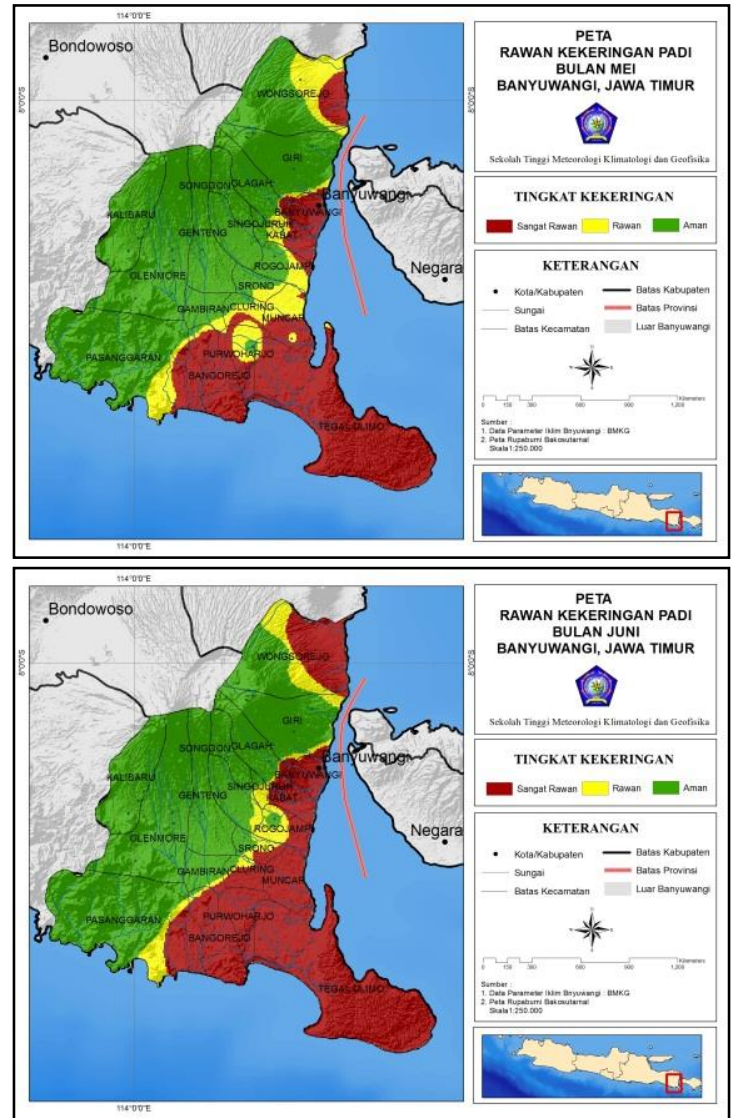

Gambar 8. Peta Kekeringan Lahan Padi Bulan Mei dan Juni

Pada bulan Mei, wilayah sangat rawan kekeringan semakin meluas dibanding bulanbulan sebelumnya. Wilayah bagian timur Banyuwangi cenderung tidak bisa ditanami padi karena rawan hingga sangat rawan terhadap kejadian kekeringan padi. Sedangkan wilayah lainnya aman untuk ditanami padi.

Pada bulan Juni, hampir mirip dengan Mei wilayah rawan kekeringannya. Wilayah bagian 
timur Banyuwangi cenderung tidak bisa ditanami padi karena rawan hingga sangat rawan terhadap kejadian kekeringan padi. Sedangkan wilayah lainnya aman untuk ditanami padi.

\section{Bulan Juli dan Agustus}

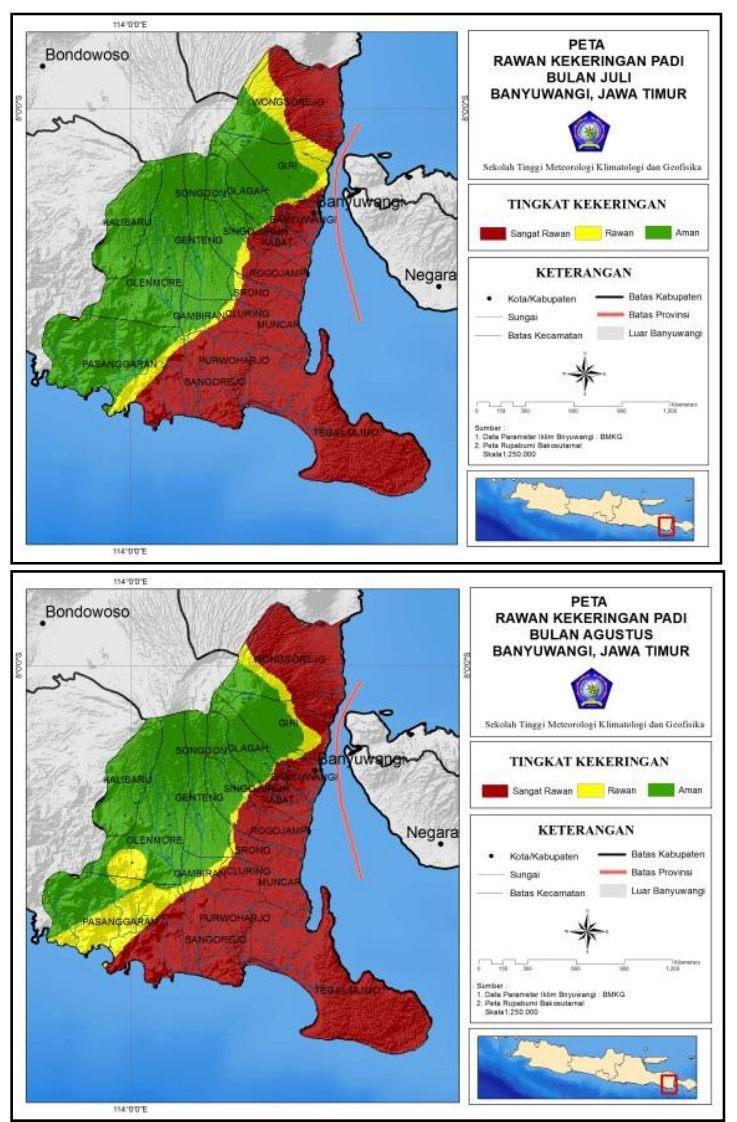

Gambar 9. Peta Kekeringan Lahan Padi Bulan Juli dan Agustus

Pada bulan Juli dan Agustus wilayah kering dan rawan kering lebih luas dibanding bulan sebelumnya. Wilayah bagian timur Banyuwangi cenderung tidak bisa ditanami padi karena rawan hingga sangat rawan terhadap kejadian kekeringan padi. Sedangkan wilayah lainnya aman untuk ditanami padi.

\section{Bulan September dan Oktober}

Pada bulan September merupakan puncak kering dan rawan kekeringan dengan wilayah yang paling luas dibandingkan dengan bulan lainnya. Wilayah bagian timur dan selatan Banyuwangi cenderung tidak bisa ditanami padi karena rawan hingga sangat rawan terhadap kejadian kekeringan padi. Sedangkan wilayah lainnya aman untuk ditanami padi.
Pada bulan Oktober juga hampir sama dengan September. wilayah bagian timur dan selatan Banyuwangi cenderung tidak bisa ditanami padi karena rawan hingga sangat rawan terhadap kejadian kekeringan padi. Sedangkan wilayah lainnya aman untuk ditanami padi.
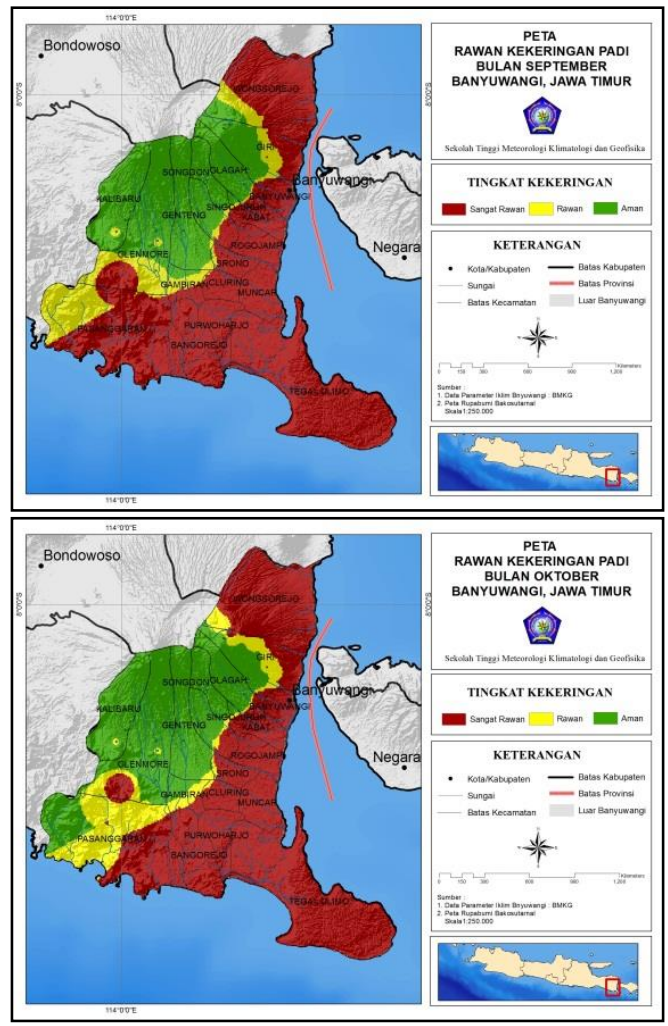

Gambar 10. Peta Kekeringan Lahan Padi Bulan September dan Oktober

\section{Bulan November dan Desember}

Pada bulan Nopember wilayah kering dan rawan kekeringan mulai berkurang dibanding bulan sebelumnya September dan Oktober. Wilayah bagian Timur Banyuwangi cenderung tidak bisa ditanami padi karena rawan hingga sangat rawan terhadap kejadian kekeringan padi. Sedangkan wilayah lainnya aman untuk ditanami padi.

Pada bulan Desember wilayah kering dan rawan kekeringan mulai berkurang lagi. Wilayah bagian timur Banyuwangi cenderung tidak bisa ditanami padi karena rawan hingga sangat rawan terhadap kejadian kekeringan padi. Sedangkan wilayah lainnya aman untuk ditanami padi. 


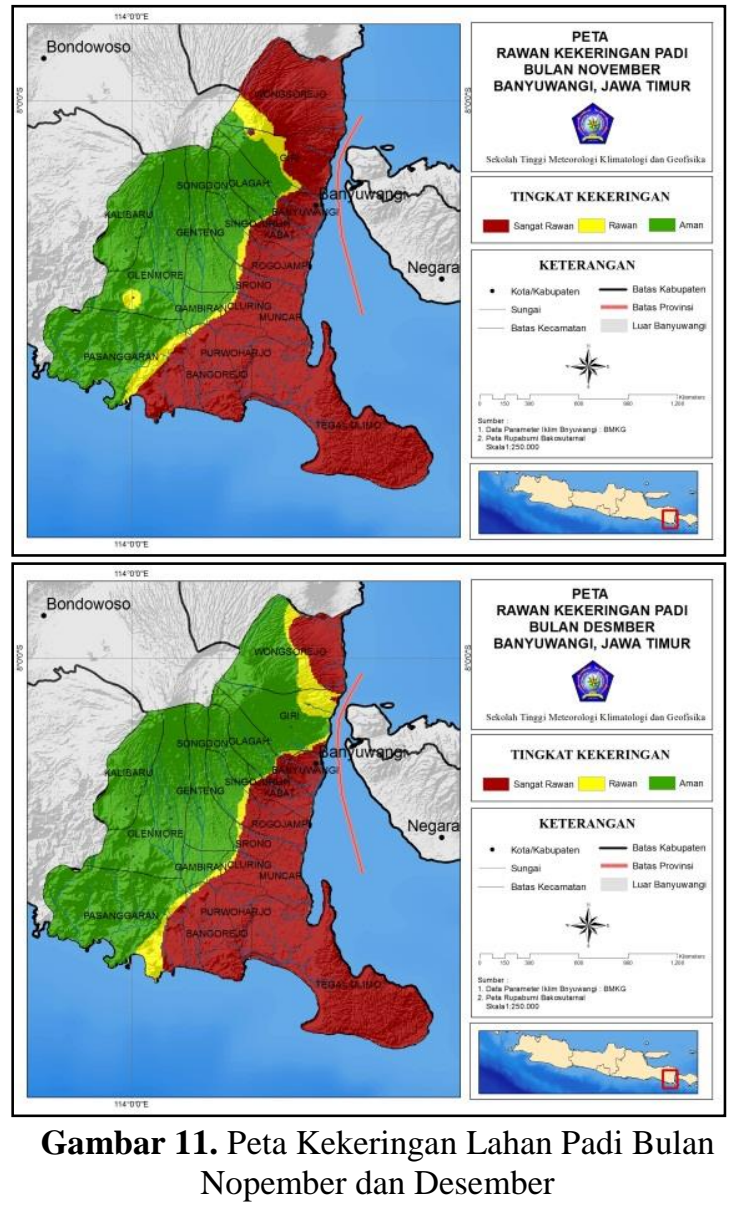

\section{KESIMPULAN}

1) Klasifikasi Oldeman di Banyuwangi terbagi menjadi 9 tipe iklim mulai dari iklim yang basah hingga kering, yaitu wilayah bagian barat cendrung lebih basah dibandingkan bagian timur. Tipe iklim D4 memiliki wilayah yang paling luas dan tipe iklim B1 memiliki luasan yang paling sempit.

2) Kondisi air tersedia di Banyuwangi pada bulan Februari, Maret, dan April lebih banyak dibandingkan bulan lainnya, sedangkan pada Agustus, September dan Oktober lebih kecil dibandingkan bulan yang lainnya. Di bagian timur Banyuwangi air tersedia mulai berkurang ketika memasuki bulan Juni dan mulai bertambah ketika memasuki bulan Desember. Secara umum wilayah bagian barat memiliki air tersedia lebih banyak dibandingkan bagian timur.

3) Tingkat kering dan rawan kekeringan padi puncaknya terjadi pada September dan Oktober dengan cakupan wilayah yang paling luas.
4) Sebagian besar wilayah mengalami tingkat yang aman untuk menanam padi adalah pada Januari, Febuari, Maret dan April.

\section{DAFTAR PUSTAKA}

Buckman, H.O., dan Brady, N. C. 1969. The Nature and Properties of Soil, 7 ed. Macmillan. New York. 653p.

Chang. 1968. The Use of Agriculture System Modeling for Crop Management: Case Study in Pusaka Negara. APN (Asian Pacific Network) Project Report.

Dinas Pertanian Perkebunan Peternakan dan Kehutanan Kabupaten Banyuwangi. 2014. Kabupaten Banyuwangi dalam Angka. Dinas P3K Banyuwangi.

Doorenbos, J., dan Pruitt, W.O., 1976. Guidelines for Predicting Crop Water Requirements. FAO Irrigation and Drainage Paper No. 24. FAO of The United Nations. Rome. 179p.

Nasir, A. A. 1991. Metode Neraca Air untuk Perencanaan Pola Tanam Pada Usaha Tani Tanaman Semusim. Kapita Selekta Dalam Agrometeorologi. IPB-Bogor. Bogor.

Oldeman, L.R., dan Frere, M. 1982. A Study of the Agrometeorology of the Humid Tropics of South East Asia. WMO No. 597. Technical Note No. 179.

Pawitan, H. 1996. Implementasi Pendekatan Strategis dan Taktis Gerakan Hemat Air. Prosiding Seminar Nasional "Pemantapan Gerakan Hemat Air untuk Mengoptimalkan Pemanfaatan Sumberdaya Air. Perhimpi. Bogor.

P3TISDA. 1988. Agrometeorological Aspects of Operational Crop Protection. Technical Note No. 192. Secretariat of the WMO, Geneva. Switzerland.

Sandy, I. M. 1987. Iklim Regional Indonesia, Jurusan Geografi FMIPA - Universitas Indonesia, Jakarta.

Thornthwaite, C.W., dan Mather, J.R. 1957. Intructions and Tables for Computing Potential Evapotranspiration and the Water Balance. Drexel Institute of Technology Laboratory of Climatology Vol.X No.3. Centerton. New Jersey. 
